\title{
Use of Social Media as a Media Promotion for Small and Medium Enterprises
}

\author{
Isma Azis Riu \\ Hasanuddin University, Indonesia \\ ismaazisriu@yahoo.com
}

\begin{abstract}
Era of information technology extremely dynamic, fast growing as it is now, allows us to communicate with anyone, anytime, anywhere cheaply and quickly crossed the line geography. Especially with social media or social media, which increasingly plays an important role in communicating and socialize? Social media is not just used by the individual. In fact there are many large companies, small and medium enterprises (SMEs), even the candidates, presidential candidates, even use it as a medium of communication and media promotion. Social Media is an online media, the users can easily participate, share and create contents include blogs, social networks, wikis, forums and virtual worlds. Blogs, social networking and wikis are forms of social media are most commonly used by people around the world. Conclusions that can be drawn is very important to use social media as a promotional medium for Small and Medium Enterprises (SMEs) in a systematic and structured, because in addition to not require huge capital, and does not require an office, could be anywhere, anytime due to real time. Range is not limited to the Internet reaches all regions and even countries. With so many current Social Media, Small and Medium Enterprise Social Media can choose which one is suitable for their products. Utilization of Social Media, can be establish communication with customers, build emotional bounding. And in this era of social media gave birth to a new customer segment called customer social (social customer), thus giving birth to new ways or practices of a business, product or service in the interaction with the market.
\end{abstract}

Keywords: Social Media, media promotion, SMES

\section{Introduction}

Era of information technology extremely dynamic, fast growing as it is now, allows us to communicate with anyone, anytime, anywhere cheaply and quickly crossed the line geography. Especially with social media or social media, which increasingly plays an important role in communicating and socialize? Social media is not just used by the individual. In fact there are many large companies, small and medium enterprises (SMEs), even the candidates, presidential candidates, even use it as a medium of communication and media promotion (Marketing Magazine, 10 edition 10, 2013). Passive customer's current era has passed. Social media has transformed them into active customers, and even tend to be hyperactive. In addition to changing the way customers communicate with business, also facilitates the adoption of social media paradigm shift in customer relations - a brand or company. Customers who used to be static, silent, suddenly now dynamic. Customers of this dynamic can be clustered or grouped into customer social (social customer). The birth of this new customer segment spawned new ways or practices of a business, product or service to interact with the market. (Majalah Mix Marketing Communication, 02, 2012, hal 28). Based on the data of Fortune, $90 \%$ of companies already have an account with at least one social media. This means that the role of social media in motion the company's business cannot be overlooked. Indonesian State thrives with social media. The country has 65 million Facebook users, about 33 million active users that it is opening up every day; 28 million are also open through mobile devices. (Majalah Marketing, edisi 10, 2013).

Internet users in Indonesia have reached 63 million people. Of that number, 95 percent use the Internet to access social networking. Director of International Information Services Directorate General of Information and Public Communication (IKP), Selamatta Sembiring said, social networking sites are the most widely accessed Facebook and Twitter. Indonesia ranks fourth largest Facebook users after the USA, Brazil, and India. "Indonesia ranks fifth largest in the world of Twitter users. Indonesia's position only lost from the USA, Brazil, Japan and the UK, "he said. According to data from Webershandwick, corporate public relations and communications services provider, for Indonesia, there are about 65 million active Facebook users. A total of 
33 million active users per day, 55 million active users who use mobile devices in accessing per month and approximately 28 million active users who use mobile devices per day. In addition to Twitter, other social networks, known in Indonesia is the Path to the number of 700,000 users in Indonesia. Line of 10 million users, 3.4 million Google+ users and Linkedlin 1 million users. Twitter users, based on data from PT Bakrie Telecom, has 19.5 million users in Indonesia of a total of 500 million global users. Twitter is one of the biggest social networks in the world so as to reap profits reached \$ 145 million.

Social Media: Social Media is an online media, the users can easily participate, share and create contents include blogs, social networks, wikis, forums and virtual worlds. Blogs, social networking and wikis are forms of social media are most commonly used by people around the world. Andreas Kaplan and Michael Haenlein define social media as "a group of Internet-based applications that build on the ideological and Web 2.0 technologies.

Social media has traits - traits as follows:

- The message conveyed is not just for one person, but can control every aspect of many people. for example a message via SMS or internet

- The message conveyed freely, without having to go through a Gatekeeper

- The message conveyed tends to be faster compared to other media

- Recipients of messages that determine the interaction time

The development of social media: The development of Social Media itself as follows :

- 1978 Beginning of the invention bulletin board system that allows it to be able to connect with others using electronic mail, or upload and download software, all this is done is by using a phone line connected to the modem

- 1995 Birth of GeoCities site, this site serves Web Hosting namely data storage rental services - the data page of the website is a website that can be accessed from anywhere, and the emergence of GeoCities is a milestone of the establishment of the website - other website.

- 1997 comes the first social networking site that is Sixdegree.com even though in 1995 there is a site that Classmates.com is also a social networking site however, is considered more Sixdegree.com offers a social networking site Classmates.com appeal

- Appeared in 1999 to create a personal blog site, namely Blogger. This site offers its users to be able to create their own Web page. So that the user of this Blogger can contain any thing about. Including personal matters or to criticize the government. So can say this blogger become a milestone in the development of social media.

- 2002 Establishment Friendster, a social networking site which at the time was a boom, and the existence of a social media is phenomenal.

- 2003 Establishment of LinkedIn, is not only useful for sociable, LinkedIn is also useful to find a job, so the function of a Social Media is growing.

- 2003 Establishment MySpace, MySpace offers ease of use, so in saying MySpace social networking site that is user friendly.

- 2004 The birth of Facebook, the famous social networking site up to date, is one of the social networking sites that have the most members.

- 2006 Birth of Twitter, a social networking site that is different from the others, because of Twitter users can only update the status or named Tweet this that only in the limit of 140 characters.

- 2007 Birth of Wiser, the first social networking sites once launched to coincide with Earth Day (April $22), 2007$. The site is expected to become an online directory of environmental organizations worldwide including both the environmental movement is done individually or in groups.

- 2011 Birth of Google+, Google launched a social networking site called Google +, but at the beginning of the launch. Google + is limited to people who have been in the invite by Google. After that Google + launched in general.

The Growth of Social Media: The rapid development of social media now because everyone could have their own media like. If to have a traditional media such as television, radio, or newspaper required substantial capital and labor that much, then another case with the media. Social media users can access using social 
media to the Internet network to which access is slow even though, without great expense, without expensive tools and conducted themselves without employees. Social media users can freely edit, add, modify text, images, video, graphics, and a variety of other content models. According to Antony Mayfield from iCrossing, social media is about being a human being. Ordinary people who share ideas, cooperate, and collaborate to create creations, thinking, arguing, find people who can become good friends, find a mate, and build a community. In essence, using social media to make us as ourselves. In addition to the speed of information that can be accessed in seconds, be yourself in social media is the reason why social media is growing rapidly. Not least, the desire for self-actualization and the need to create personal branding. The development of social media is really fast, it can be seen from the large number of members who owned each - each of these social networking sites, the following table the number of members of each - each site in the quotation from (Grant \& Meadows, 297) at 1 may 2010:

\begin{tabular}{lll}
\hline No & Social Media & Member \\
\hline 1 & facebook & 250.000 .000 \\
2 & MySpace & 122.000 .000 \\
3 & twitter & 80.500 .000 \\
4 & LinkedIn & 50.000 .000 \\
5 & ning & 42.000 .000 \\
\hline
\end{tabular}

Social networking is a site where everyone can create a personal web page, then connect with friends to share information and communicate. Largest social networking, among others Facebook, MySpace, Plurk, and Twitter. If traditional media use print and broadcast media, the social media using the internet. Social media invite anyone who is interested in berpertisipasi to contribute openly and feedback, comment, and share information in a fast and unlimited. When the Internet and mobile phone technology more advanced then social media, too, is growing rapidly. Now to access facebook or twitter for example, can be done anywhere and anytime just by using a mobile phone. So fast people can access social media resulted in a major phenomenon of the flow of information not only in developed countries, but also in Indonesia. Because the speed of social media also began to appear replace the conventional mass media role in spreading the news..

\section{Some media potential is used as a Media Promotion}

A. Facebook is a social networking service launched in February 2004, is owned and operated by Facebook, Inc. In September 2012, Facebook has more than one billion active users, [7] more than half using a mobile phone. Users must register before you can use this site. After that, the user can create a personal profile, add other users as friends, and exchange messages, including automatic notifications when they update their profile. Additionally, users can join a group of users with the same interests, sorted by workplace, school or college, or other distinctive characteristics, and categorize their friends into lists such as "Partners" or "Close Friends". Facebook was founded by Mark Zuckerberg with his college roommates and fellow students of Harvard University, Eduardo Saverin, Andrew McCollum, Dustin Moskovitz and Chris Hughes. This web site membership was initially limited to Harvard students, then expanded to other colleges in the Boston, Ivy League, and Stanford University. This site is slowly opening up to students at various other universities before opening to high school students, and ultimately for each person aged 13 years. Even so, according to Consumer Reports survey of May 2011, there were 7.5 million children under the age of 13 years who have a Facebook account and another 5 million are under 10 years old, thus violating the terms of service of this site. January 2009 Compete.com study puts Facebook as a social networking service that is most widely used according to the number of monthly active users worldwide. Entertainment Weekly put it on the list of "best" end of the decade with the comment, "How did we stalk our former lover, remembering the birthday of our co-workers, friends annoy us, and playing Scrabulous before Facebook was created?". Quantcast estimates Facebook has 138.9 million monthly visitors in the US in May 2011. According to Social Media Today, in April 2010, approximately $41.6 \%$ of the US population has a Facebook account Nevertheless, the growth of Facebook market began to fall in some areas with a loss of 7 million active users in the United States and Canada in May 2011. The service name is derived from the name of books given to students at the start of the 
academic year by university administrations in some of the United States to help students get to know each other. Facebook allows anyone aged 13 and over become a registered user on this site.
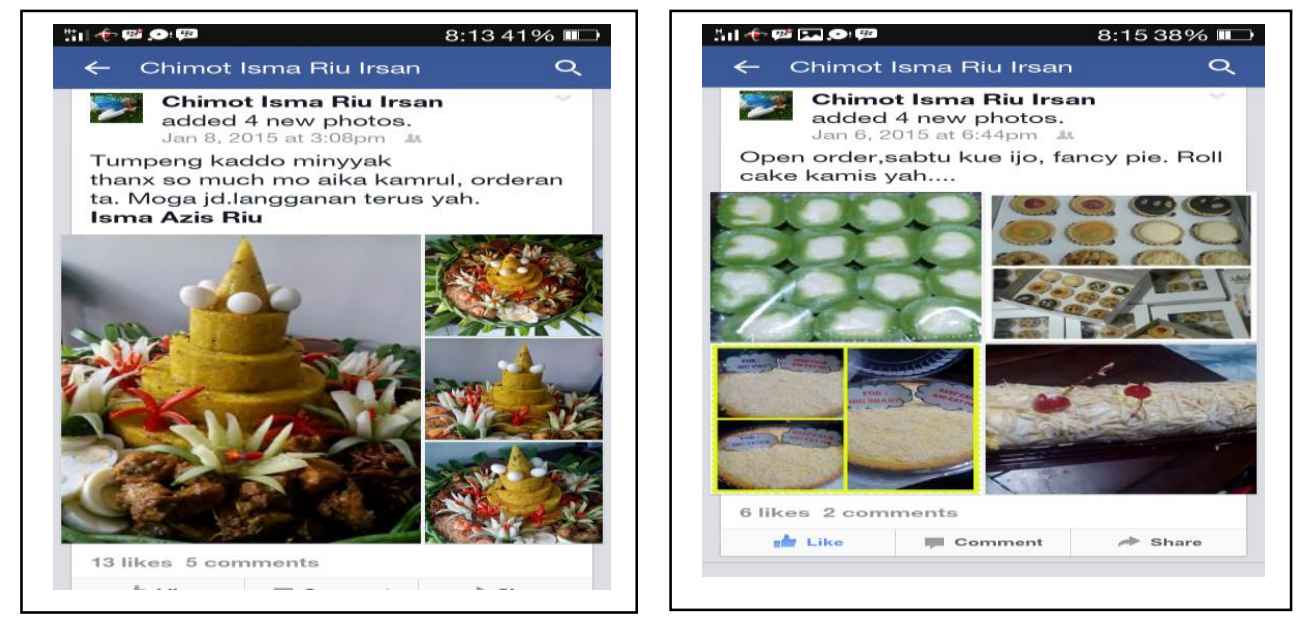

B. Twitter is a social networking and micro-blogging service that enables online users to send and read textbased messages of up to 140 characters, known as tweets (tweet). Twitter was founded in March 2006 by Jack Dorsey, and a social networking site launched in July. Since its launch, Twitter has become one of the top ten most visited sites on the Internet, and dubbed the "short message from the Internet." On Twitter, unregistered users can only read chirp, while registered users can posting chirp through the web site interface, short messages (SMS), or through a variety of applications for mobile devices. Twitter has grown rapidly and quickly gained popularity throughout the world. Until January 2013, there were more than 500 million registered users on Twitter, 200 million of whom are active users. The surge in the use of Twitter in general took place during the events popular. In early 2013, Twitter users send more than 340 million tweets per day, and Twitter handles more than 1.6 billion search queries per day. This causes Twitter position up to second as social networking sites most visited in the world, of which previously was ranked twenty-two. The high popularity of Twitter is causing this service has been used for various purposes in various aspects, for example as a means of protest, political campaigns, learning tools, and as an emergency communication media. Twitter is also faced with various problems and controversies such as security and user privacy issues, lawsuits, and censorship. Twitter is owned and operated by Twitter, Inc., based in San Francisco, with offices and additional servers are in New York City, Boston, and San Antonio.

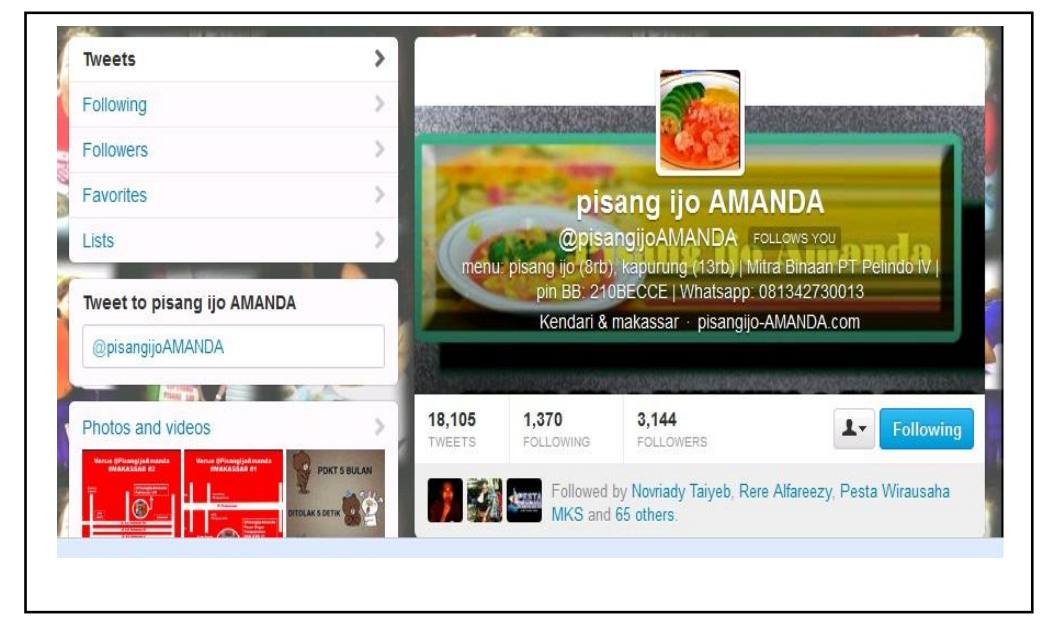

C. Instagram is a photo sharing application that allows users to take photos, apply a digital filter, and distributed to various social networking services, including those of its own Instagram. One unique feature in Instagram is a photo cut into a square shape, so it looks like the result of Kodak Instamatic and Polaroid 
cameras. This is different from the aspect ratio of $4: 3$ which is commonly used by the camera on mobile devices. Instagram can be used on iPhone, iPad or iPod Touch with any version of the operating system iOS 3.1.2 or later and any camera phone with the operating system Android 2.2 (Froyo) or later. This application is distributed through Apple's App Store and GooglePlay. On April 9, 2012, it was announced that Facebook agreed to take over Instagram with a value of approximately $\$ 1$ billion. Instagram The name comes from the understanding of the overall function of this application. The word "insta" comes from the word "instant", like the Polaroid camera in his time better known as "instant photo". Instagram also can display the photos in an instant, like a Polaroid in zoom. As for the word "gram" is derived from the word "telegram", which telegram own way of working is to send information to others quickly. Similar to Instagram to upload photos using the Internet network, so that information can be conveyed quickly accepted. Therefore Instagram comes from instant-telegram.

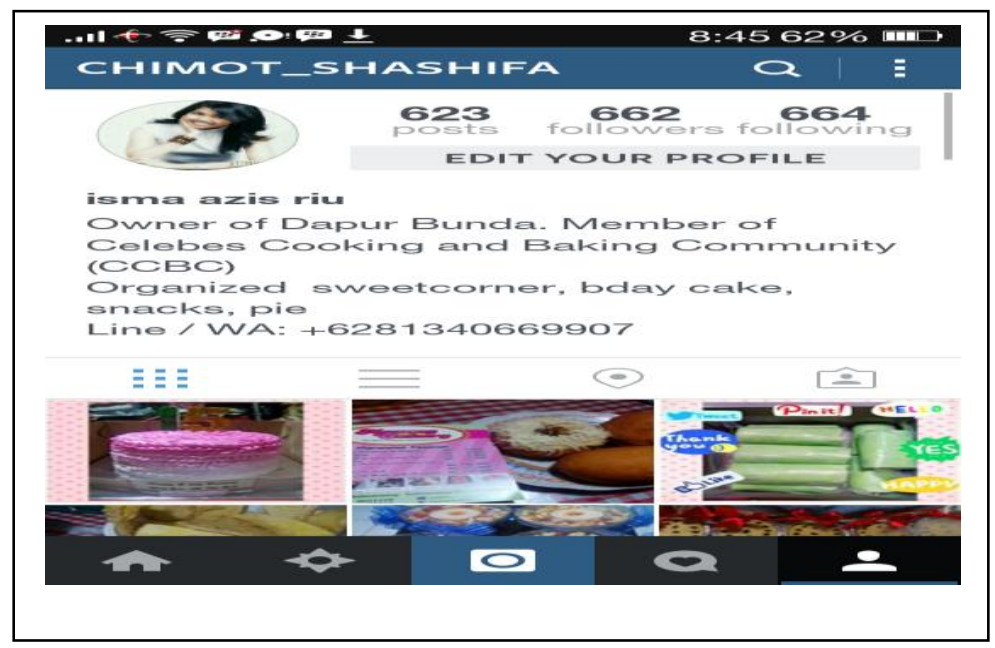

D. Path is a social networking application on a smart phone that allows users to share images and messages. The use of Path targeted to be a separate place for users to share with family and closest friends. Dave Morin, one of the founders of Path and CEO of the company said: "That became our main vision is to create a network with high quality and makes users comfortable to contribute every time." The company started with the application on the iPhone and the website also released the Android version later. The company is competing with other social networks like Instagram. Headquartered in San Francisco, California, the company was founded by Shawn Fanning and former executive of Facebook, Dave Morrin. Path was founded with the purpose of making an interactive journal for its users. Use a different path than other social networks where only approved users can access the page Path someone. Privacy status of this application makes more exclusive Path from different social networks. The path can be used on iPhone, iPad, iPod Touch, and Android versions of any kind. This application is distributed through the Apple Application Store and various other application sites.
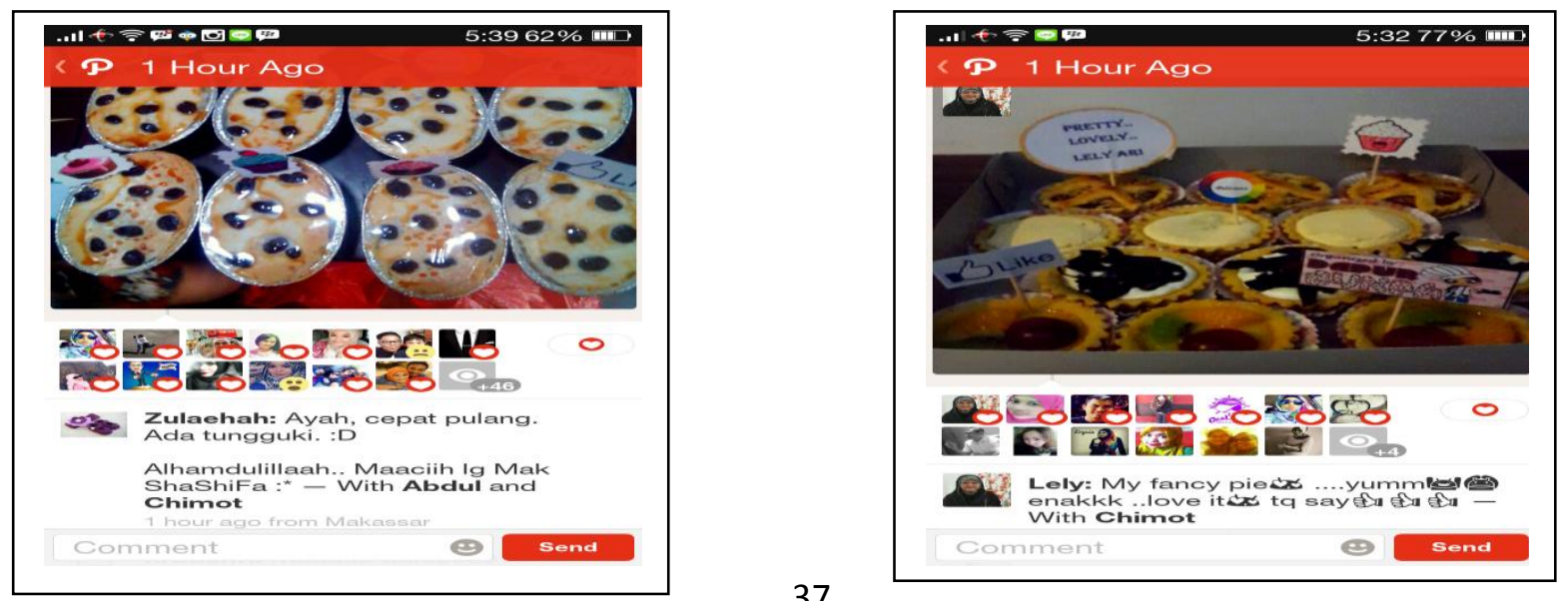
Five years ago, the social networking users in Indonesia is not too significant, is still in the range of millions of people. Large spikes emerge from the latest data reported by the Association of Indonesian Internet Service Provider (APJII). In accordance APJII survey last year, 63 million people of Indonesia are connected to the Internet. As many as 95 percent of the population activity when accessing the virtual world is open social media. Indonesia predicted soon be the country of origin of the most active users of social media, and of course, the biggest in terms of number. The reason of course, because the price of smart mobile phones (smartphones) are increasingly affordable for all circles. The smartphone market in 2013 is predicted to grow 44 percent, or the equivalent of 40,000 units added. Of all citizens of this country who have a mobile phone, 15 percent have a smartphone. Director of International Information Services Administrator, Selamatta Sembiring, judge, people in the country are very crazy for exist in cyberspace. As a result of other functions of the Internet in this country rather marginalized. "Advances in Internet technology is used to simply update the status or mutual also chimed comments or photos uploaded to Facebook and Twitter," he said in a seminar in Bogor last month.

Global Web Index Survey data also confirms that Indonesia is a country whose citizens infatuated with social media. The percentage of social networking activities Indonesia reached 79.72 percent, the highest in Asia, beating the Philippines (78 percent), Malaysia (72 percent), China (67 percent). Even Asian countries with advanced Internet technology social media utilization is low, for example, South Korea (49 percent) or Japan (30 percent). In particular, the survey institute Brand24 even ordain Jakarta as the capital city in the world of social media. In various social networks, the amount of activity of Jakarta per day, on average, greater than any other country. Not less, social media company officials famous as Path, already monitor how Internet users in the country infatuated with the concept of online friends. This is why Indonesia so coveted companies around the world as a social media business market. "I noticed a lot of social networking users in this country makes various accounts to attract more friends. Residents and Indonesian culture I noticed quite innovative with social networking. The country is certainly going to be a big market for us," said CEO Dave Morin Path. Then, in social media any Indonesian citizens become one of the largest and most active users? Here summarized as merdeka.com collected from various sources.

Indonesia is one of the major markets for the social networking site Facebook. According to the data from the survey up, every day, 33 million inhabitants of this country open social media-made Mark Zuckerberg was on the computer. Active users access Facebook from his cell phone about 28 million people.? While the monthly recap, 65 million citizens of Indonesia opened up. That is, the number of users of social networking was more than the total Internet users in Indonesia version APJII survey. Globally, Facebook users from Indonesia the third highest in the world. In fact, in 2011, the actual users of social media it was familiarly called Fb exactly was second after the United States. According to Eileen, currently too many people involved in the internet. They interact with each other socially, based on mutual trust and communal. This phenomenon makes the explosion of digital interactivity and the relationship became so Kual. In this situation, social networking at the heart of this connection is successful when it is able to create, maintain and grow a valuable interaction. If it's successful business network can grow and thrive. This means that companies that have effective social engagement strategy with implementation planning is managed by the timescale and structured, will be able to find their customers, identify who the movers and shakers, as well as effectively connected with them. (Brown, 2010)

\section{The advantage of using Social Media to promote:}

- Does not require major capital today cukupmenggunakan Laptop or Mobile with Internet network. No need to rent an office. You could be anywhere to go online.

- Can reach infinite market. Internet reaches into all areas, even across the State.

- Reach indefinitely. Can run 24 hours a day, 7 days a week. Provided that we've built a business on the internet, then the system will continue to run our business. Because it is a real time then in a matter of hours alone can be a response back from the social media user.

- Easy on the run and bring promising material benefits. Save time and effort 


\section{Shortage in Social Media Promotion:}

- If the products and services offered by the manufacturer has a quality that let the users of social media can be very easily expressed disappointment via social media, even to revile the product or service. This course will only damage the image of the product or service being offered.

- The products and services offered in the social media should also be specially managed and not arbitrary. It is important to maintain the image of the products and services offered in the social media.

- Sometimes abused by customers who say it transfers while yet, and ask for the goods shipped.

- Customers can not hold or select items directly, only through photographs.

Promotion: Well, to reflect on these facts, it is no wonder that social media is an opportunity to bring a product or service as a solution to the problems they have. With an approach that tends to "soft", is expected to lead a consumer opinion will be a brand that is offered by the business owner. Not only in terms of sheer business, they are engaged in social even have taken advantage of social media prowess. In fact, an artist can feel the benefits of networking sites that they have to get closer to his fans. However, like two sides of a coin where the advantages offered tucked deficiency to watch. If not, then be prepared to face all the things that are lower levels of trust for online media prefers it. Promotion methods that are too forced and often unrecognized by businesses are also suspected to be able to lose a sense of ownership of the products or services which led to the deletion of your account. For those who want to use social media as a marketing tool that is fairly powerful and effective, it is necessary to understand the technique or approach of each social site. Whether it's facebook, twitter to other social media to deliver the results as expected. Promotion is one of the factors determining the success of a marketing program. However berkualitasnya a product, if consumers have never heard of and are not sure that the product that will be useful to them, then they will never buy it (Tjiptono, $2008: 219$ ). According Sistaningrum (2002) campaign is an effort or activity affecting the company in the "current customers" or "potential customers" in order for them to make purchases of products offered, present or future.

According to Belch and Belch (2009) promotion as coordination of all efforts from the seller to open lines of information and persuasion in order to sell goods and services. According Grewal and Levy (2008) as a promotional communications made by marketers to inform, persuade and remind potential buyers of the products or services to influence the opinion of buyers and elicit a response from the buyer. According to Kotler (2006) is the promotion of the activities undertaken between companies to communicate the benefits of its products and to ensure that the target consumers buy. Of the various definitions of the above, it can be stated promotion is one of the variables in the marketing mix should the firm to provide information about products or services, as well as persuade and remind consumers to make purchases of goods and services. According Tjiptono (2008) the main goal of the campaign is to inform, influence and persuade, and remind target customers about the company and its marketing mix. The detailed objectives of the campaign can be described as follows:

A. Inform can be:

- Inform the market about the existence of a new product

- Introducing a new way of use of the existence of a product

- Delivering changes to the market price

- Explains the workings of a product

- Inform the services provided by the company services

- Align the mistaken impression

- Reduce fears or concerns buyers

- Building a corporate image

B. Persuade targeted customers to:

- Establish brand choice

- Switch the option to particular brands

- Changing customer perceptions of product attributes

- To encourage shoppers to spend that time also

- To encourage the buyer to receive a visit salesperson 
C. Reminding, may consist of:

- Remind buyers that the products concerned are needed in the near future

- Remind pembeliakan places that sell products company

- Make buyer still remember though no advertising campaign

- Keeping the memory of the first buyers fall in the company's products.

\section{Small and Medium Enterprises (SMEs)}

Definition of medium-sized businesses: Medium referred Instruction No.10 of 1998 was productive businesses that meet the criteria of net wealth greater effort than Rp200.000.000,00 (two hundred million dollars) up to the maximum amount of Rp10,000,000,000.00, (ten billion dollars), excluding land and buildings, and can receive credit from the bank for Rp.500.000.000,00 (five hundred million rupiah) s / d Rp.5.000.000.000,00 (five billion dollars).

The characteristics of medium-sized businesses:

- In general, management and organization have to have a better, more organized and even more modern, with a clear division of tasks among others, finance, marketing and production;

- It has been doing financial management by implementing accounting systems regularly, making it easier for auditing and assessment or inspection, including by banks;

- Have done the rules or management and labor organizations, has no Social Security, health care etc;

- It has all the legal requirements among other neighbors permits, business licenses, permits spot, TIN, environment management etc;

- It has access to bank financing sources;

- In general, human resources have been trained and educated.

Examples of medium-sized businesses: Types or kinds of medium-sized enterprises working almost commodities of almost all sectors might almost evenly, namely

- Agriculture, animal husbandry, agriculture, forestry medium scale;

- Trade (wholesale) including export and import;

- EMKL business services (Sea Cargo), garment and taxi and bus transportation services between proponsi;

- Industrial enterprises of food and beverage, electronics and metals;

- Mining the mountain stone for construction and artificial marble.

Criteria for small businesses, according to Law No. 91995 are as follows:

- It has a net worth of Rp. 200.000.000, - (Two Hundred Million) excluding land and buildings

- It has annual sales of Rp. 1,000,000,000, - (One Billion Rupiah)

- Owned Indonesian citizen

- Stand-alone, not subsidiaries or branches of companies that are not owned, controlled by, or affiliated directly or indirectly with Medium or Large Business

- Shaped individual business, business entity that is not a legal entity, or a business entity with legal status, including cooperatives.

\section{Conclusion}

Social Media is very important to use as a media campaign for the Small and Medium Enterprises (SMEs) in a systematic and structured, because in addition to not require a large capital, and does not require an office, could be anywhere, anytime due to real time. Range is not limited to, the Internet reaches all regions and even countries. With so many current Social Media, Small and Medium Enterprise Social Media can choose which one is suitable for their products. Utilization of Social Media, can be establish communication with customers, build emotional bounding. And in this era of social media gave birth to a new customer segment called customer social (social customer), thus giving birth to new ways or practices of a business, product or service in the interaction with the market. 


\section{Reference}

Bambang Wintoko. Kiat Ampuh Berbisnis \& Menggaet Mitra Melalui Dunia Maya. Panduan Sukses Bisnis dan Bermitra Lewat Internet.

Brown, E. (2010). Working the Crowd : Social Media Marketing for Business. 2010. British Informatics Society Limited.

Belch, G. E. \& Belch, M. A. (2009). Advertising and Promotion: An Integrated Marketing Communication Perpective. 8th Edition. New York : McGraw-Hill.

http://latiefpakpahan.com/media-sosial-sebagai-alat-pemasaran/

http://hendrausahakecil.blogspot.com/

http://harianti.com/ini-data-jumlah-pengguna-media-sosial-di-indonesia/

http://id.wikipedia.org/wiki/Media_sosial

http://id.wikipedia.org/wiki/Facebook

http://id.wikipedia.org/wiki/Twitter

http://id.wikipedia.org/wiki/Instagram

http://id.wikipedia.org/wiki/Path_\%28jejaring_sosial\%29

http://www.merdeka.com/uang/di-5-media-sosial-ini-orang-indonesia-pengguna-terbesar-dunia/path.html http://latiefpakpahan.com/media-sosial-sebagai-alat-pemasaran/

(http://hendrausahakecil.blogspot.com/)

http://www.duniaprofesional.com/dunia-kerja/kelebihan-dan-kekurangan-pemasaran-di-sosial-media/

Grant, A. E. \& Meadows, J. H. (2010). Communication Technology Update and Fundamental.12th Edition.Boston: Focal Press

Grewal, D. \& Levy, M. (2008). Marketing New York: McGraw-Hill Companies Inc.

Kaplan, A. M. \& Michael, H. (2010). Users of the world, unite! The challenges and opportunities of Social Media. Business Horizons, 53(1), 59-68.

Kotler, P. A. G. (2006). Principles of Marketing. 11 ${ }^{\text {th }}$.Edition. New Jersey: Prentice Hall. Pearson Education, Inc., Upper Saddle River, New Jersey.

Majalah Mix Marketing Communication, 02, 2012, hal 28.

Majalah Marketing, edisi 10, 2013.

Sistaningrum, Widyaningtyas. 2002. Manajemen Penjualan Produk. Yogyakarta, Kanisius.

Tjiptono, F. (2008). Strategi Pemasaran. Edisi III. Penerbit Andi. 